\title{
Pelatihan Penerapan Multimetode dalam Pengembangan Perilaku Anak Usia Dini Bagi Guru TK/PAUD Gugus Muara Tami Kotamadya Jayapura
}

\author{
Oleh: \\ Sirjon$^{1}$, Endang Sri Mulyanie ${ }^{2}$ \\ ${ }^{1}$ Program Studi PG-PAUD Universitas Cenderawasih \\ sirjon@fkip.uncen.ac.id
}

\begin{abstract}
Abstrak
Usia dini merupakan masa emas untuk mengembangkan sikap, rasa, pikiran serta perilaku anak. Adanya pelatihan, pengkondisian serta pemberian stimulasi secara berkelanjutan dengan cara yang tepat dan positif akan membantu pencapaian tugas perkembangan anak secara optimal. Oleh karena itu pemahaman yang baik terhadap berbagai aspek perkembangan anak, strategi atau metode pengembangan dan penilaian terhadap perkembangan anak merupakan hal penting yang wajib dimiliki dan dikuasai oleh guru TK/PAUD. Tujuan pengabdian ini adalah untuk memfasilitasi Guru TK/PAUD yang ada di Gugus Muara Tami Kotamadya Jayapura untuk mengembangkan keterampilan dan kompetensinya dalam menerapkan multimetode dalam pengembangan perilaku anak usia dini. Metode yang diterapkan dalam kegiatan ini adalah training, sharing knowledge dan praktik langsung. Hasil kegiatan ini menunjukkan adanya peningkatan keterampilan dan kemampuan peserta dalam menerapkan multimetode dalam pengembangan perilaku anak usia dini, dimana dari 26 peserta terdapat 20 peserta $(76,92 \%)$ yang termasuk kategori sangat baik dan 6 peserta $(23,08 \%)$ termasuk kategori baik.
\end{abstract}

Kata Kunci: Multimetode, Perilaku, Usia Dini.

\begin{abstract}
Early childhood is a golden period for developing children's attitudes, feelings, thoughts and behavior. The existence of training, conditioning and continuous stimulation in an appropriate and positive way will help achieve optimal child development tasks. Therefore a good understanding of various aspects of child development, strategies or methods of development and assessment of child development is an important thing that must be owned and mastered by kindergarten / early childhood teachers. The purpose of this service is to facilitate kindergarten / early childhood teachers in the Muara Tami Cluster, Jayapura Municipality to develop their skills and competencies in implementing multimethods in developing early childhood behavior. The methods applied in this activity are training, sharing knowledge and direct practice. The results of this activity indicate an increase in the skills and abilities of participants in implementing multimethods in the development of early childhood behavior, where of the 26 participants there were 20 participants $(76.92 \%)$ who were in the very good category and 6 participants (23.08\%) were in the good category.
\end{abstract}

Keywords: Multimethods, Behavior, Early Age.

\section{PENDAHULUAN}

Proses pendidikan mempunyai peranan penting dalam upaya mengoptimalkan potensi dan keterampilan seseorang. Oleh karenanya pendidikan harus diberikan sejak usia dini sehingga kemampuan serta keterampilan yang dimiliki oleh individu dapat dikembangkan secara maksimal. Hal ini sangat penting karena rangsangan atau stimulus dari lingkungan sekitar anak sangat cepat untuk diterima dalam rangka mengembangkan berbagai aspek perkembangannya. Menurut Erikson (Helms \& Turner, 1994) usia dini merupakan fase sense of inisiative dimana anak harus difasilitasi untuk dapat mengembangkan sikap inisiatif dalam dirinya. Berdasarkan Permendiknas Nomor 98 tahun 2009 mengenai Standar PAUD (Gunarti, Suryani, Muis, \& Pratiwi, 2018), Struktur Program PAUD yang dikembangkan di Lembaga PAUD mencakup 2 bidang, yaitu: (1) pembentukan perilaku, dan (2) pengembangan kemampuan dasar. Pembentukan perilaku mencakup dua aspek, yaitu pengembangan nilai moral dan agama; dan aspek sosial emosi.

Pengembangan kemampuan dasar mencakup 3 aspek, yaitu pengembangan fisik motorik, pengembangan bahasa, dan pengembangan 
kognitif. Perilaku merupakan hal penting yang harus dikembangkan pada anak. Menurut (Notoatmodjo, 2003), perilaku merupakan semua bentuk tindakan atau perbuatan yang ditunjukkan oleh makhluk hidup. Pengembangan perilaku yang dimaksud dapat berupa perilaku sosial atau perilaku moral. Dewi (Jahja, 2011) memberikan definisi perilaku moral sebagai perilaku yang didasarkan pada kode moral yang berlaku di dalam suatu kelompok sosial. Piaget \& Kohlberg (Adisusilo, 2012) menyatakan bahwa tolak ukur untuk menyatakan suatu perilaku moral dilihat dari adanya pertimbangan rasional secara sadar dalam melakukan suatu perilaku.

Kegiatan pengembangan aspek-aspek tersebut dilaksanakan secara terpadu dengan menggunakan pendekatan tematik dan berbagai metode pembelajaran. Penerapan berbagai metode pembelajaran dalam upaya mengembangkan aspek perkembangan anak merupakan suatu keharusan bagu guru TK/PAUD. Dalam penerapan berbagai metode pembelajaran, guru seyogianya dapat memberikan reward sebagai konsekuensi dari setiap tingkah laku positif yang ditunjukkan oleh anak, sehingga mereka memiliki motivasi dan semangat yang tinggi untuk memunculkan kembali (memperkuat) perilaku yang sudah ada (Sirjon, Mulyanie, \& Tumaruk, 2021)

Berdasarkan analisis situasi yang dilakukan pada komunitas sasaran, diperoleh informasi bahwa masih banyak guru TK/PAUD di Gugus Muara Tami Kotamadya Jayapura yang mengalami kesulitan dalam menerapkan metode pembelajaran yang tepat dalam mengembangkan perilaku anak. Latar belakang pendidikan guru PAUD/TK di Distrik Muara Tami, Kotamadya Jayapura adalah sebanyak $40 \%$ guru berpendidikan S1, dan sisanya D2 dan SLTA. Sekalipun terdapat $40 \%$ guru yang memiliki latar belakang pendidikan $\mathrm{S} 1$, tetapi tidak semuanya memiliki latar belakang pendidikan anak usia dini. Hal tersebut menyebabkan kurangnya pengetahuan guru tentang penerapan metode pembelajaran yang tepat dalam mendukung pengembangan perilaku anak. Oleh karena itu, hasil analisis situasi yang dilakukan menjadi dasar pelaksanaan kegiatan pengabdian ini. Alternatif pemecahan masalah yang sesuai dengan karakteristik sasaran sangat mendukung pencapaian tujuan yang telah ditetapkan. Alternatif tersebut diantaranya dapat dilakukan melalui kegiatan seminar, sosialisasi dan pelaksanaan workshop atau pelatihan.

Alternatif pemecahan masalah yang dipilih dalam kegiatan ini berupa pelatihan penerapan multimetode dalam pengembangan perilaku anak usia dini. Kegiatan dalam bentuk pelatihan ini merupakan alternatif pemecahan masalah yang terbaik dan paling tepat bagi sasaran, sebab kegiatan seminar, dan sosialisasi hanya dapat memberikan pemahaman teoritik kepada sasaran tanpa adanya usaha konkrit untuk mengembangkan kompetensinya terutama yang berkaitan dengan nilai moral dan agama dan sosial emosional. Sedangkan kegiatan pelatihan, selain memberikan pemahaman teoritik kepada sasaran, kegiatan tersebut lebih berorientasi pada pengembangan kompetensi sasaran untuk dapat menerapkan multimetode dalam pengembangan nilai moral dan agama serta sosial emosional anak.

Upaya untuk mengembangkan perilaku dan kemampuan dasar di TK/PAUD dilakukan melalui penerapan kegiatan bermain sambil belajar. Kegiatan pembelajaran di TK/PAUD dilakukan dengan menggunakan berbagai metode/ banyak variasi metode secara terpadu agar mencapai hasil yang diinginkan. (Gunarti, Suryani, Muis, \& Pratiwi, 2018) menyatakan bahwa, kegiatan pembelajaran di TK/PAUD tidak cukup menggunakan ceramah dan bercakap-cakap saja , karena daya konsentrasi anak masih sangat minim atau terbatas (3-4 menit saja) sehingga akan menimbulkan rasa bosan dalam pembelajaran.

Oleh karena itu dalam merancang kegiatan pembelajaran (yang disusun dalam bentuk RPPH), guru perlu memadukan beberapa metode (menggunakan multimetode) pembelajaran guna menarik minat belajar anak. (Gunarti, Suryani, Muis, \& Pratiwi, 2018) mengemukakan beberapa metode yang dapat diterapkan di TK/PAUD diantaranya metode bercerita, bercakap-cakap, pemberian tugas, tanya jawab, eksperimen, karyawisata, bermain peran, demonstrasi, serta metode proyek. Sedangkan (Ismaniar, 2010) memberikan alternatif metode yang dapat digunakan untuk pengembangan anak, diantaranya: bercakap-cakap, bermain, demontrasi, karyawisata, bermain peran, pemberian tugas, serta bercerita.

\section{METODE}

Kegiatan pengabdian ini dilaksanakan di TK Aisyiah Koya Timur. Distrik Muara Tami, Kotamadya Jayapura pada tanggal 07 September 2019. Peserta dalam kegiatan ini adalah Guru TK/PAUD yang ada di Gugus Muara Tami Kotamadya Jayapura yang berjumlah 26 orang. Metode yang diterapkan dalam kegiatan ini adalah training, sharing knowledge dan praktik langsung. Materi yang diberikan antara lain: 1) Struktur program yang dikembangkan di lembaga PAUD; 2) Bidang-bidang pengembangan pembentukan perilaku anak; 3) Pengembangan nilai moral dan agama; 4) Pengembangan aspek sosial emosional anak; 5) Alasan pentingnya penggunaan multimetode dalam pembelajaran di PAUD; 6) Metode pembelajaran di lembaga PAUD; 7) Metode pembelajaran dalam pengembangan nilai moral dan agama; 8) Metode pengembangan sosial emosional; 9) Penyusunan RPPH; 10) Praktek penerapan multimetode dalam pembelajaran.

\section{HASIL DAN PEMBAHASAN}


Dalam usaha untuk mengetahui tingkat keberhasilan kegiatan ini, maka dilakukan evaluasi dengan berbagai cara, yaitu tanya jawab untuk mengetahui pemahaman peserta tentang penerapan multimetode dalam pengembangan perilaku, yang meliputi nilai moral dan agama serta sosial emosional. Evaluasi dilakukan melalui observasi atau pengamatan terutama selama kegiatan berlangsung untuk mengetahui animo dan partisipasi aktif peserta selama kegiatan berlangsung; pembuatan RPPH dan praktek langsung berdasarkan RPPH yang sudah disusun. Hasil evaluasi yang dilakukan menggambarkan daya serap, pemahaman serta keterampilan yang peserta peroleh serta manfaat atau nilai tambah setelah peserta mengikuti kegiatan ini. Pada akhir kegiatan, peserta mendapatkan kesempatan dalam menyampaikan kesan terhadap kegiatan yang sudah dilaksanakan. Berdasarkan pesan dan kesan yang disampaikan oleh peserta yang mewakili peserta kegiatan ini, diperoleh informasi bahwa peserta sangat senang dalam mengikuti kegiatan dan menyatakan kegiatan ini sangat bermanfaat, apalagi bagi guru-guru yang tidak berlatang belakang pendidikan guru PAUD/TK dan atau guru-guru yang pengalamannya menjadi guru PAUD/TK masih relatif baru. Sebagai tindak lanjut evaluasi keberhasilan kegiatan, maka dilakukan evaluasi terhadap kemampuan sasaran dalam menyusun rencana pelaksanaan pembelajaran harian yang mencerminkan penggunaan multimetode dalam pengembangan nilai moral dan agama serta sosial emosional anak. Sedangkan pada akhir kegiatan evaluasi dilakukan terhadap kemampuan mendemonstrasikan penerapan multimetode berdasarkan rencana pelaksanaan pembelajaran harian yang telah disiapkan. Adapun kriteria keberhasilan kegiatan pengabdian yang ditetapkan adalah minimal $75 \%$ dari jumlah sasaran Masuk dalam kategori penilaian Baik. Kriteria penilaian yang digunakan yaitu:

Tabel 1. Kriteria Penilaian

\begin{tabular}{clc}
\hline No & Kriteria Penilaian & Total \\
\hline 1 & Sangat tidak baik & $20-36$ \\
2 & Kurang baik & $37-52$ \\
3 & Cukup baik & $53-68$ \\
4 & Baik & $69-86$ \\
5 & Sangat baik & $87-100$ \\
\hline
\end{tabular}

Berdasarkan hasil evaluasi yang dilaksanakan, diperoleh hasil:

Tabel 2. Hasil Evaluasi

\begin{tabular}{clcc}
\hline No & $\begin{array}{l}\text { Kriteria } \\
\text { Penilaian }\end{array}$ & f & $\begin{array}{c}\text { Persentase } \\
(\%)\end{array}$ \\
\hline 1 & Sangat baik & 20 & 76,92 \\
2 & Baik & 6 & 23,08 \\
3 & Cukup baik & 0 & 0 \\
4 & Kurang baik & 0 & 0 \\
5 & $\begin{array}{l}\text { Sangat tidak } \\
\text { baik }\end{array}$ & 0 & 0 \\
\hline
\end{tabular}

\begin{tabular}{lll}
\hline Jumlah & 26 & 100 \\
\hline
\end{tabular}

Hasil evaluasi pada tabel 2 menunjukkan bahwa terdapat 20 peserta (sebesar $76,92 \%$ ) yang berada pada kategori sangat baik, 6 peserta (sebesar 23,08\%) ada pada kriteria baik. Pada kategori cukup baik, kurang baik, serta sangat tidak baik masing-masing sebanyak $0 \%$. Oleh karenanya, kegiatan ini dinyatakan berhasil mencapai kriteria keberhasilan yang ditetapkan yaitu minimal $75 \%$ peserta berada pada kategori baik. Keberhasilan kegiatan pengabdian ini tidak terlepas dari efektivitas metode kegiatan yang diterapkan dalam pelaksanaan pelatihan ini (training, sharing knowledge dan praktik langsung). Metode tersebut terbukti efektif dalam meningkatkan kemampuan dan kompetensi peserta untuk menerapkan multimedode dalam pengembangan perilaku anak usia dini. Keberhasilan tersebut sejalan dengan hasil penelitian dan pengabdian sebelumnya yang dilakukan oleh (Muthmainnah, Maryatun, \& Cholimah, 2015) bahwa metode ceramah dan tanya jawab, simulasi permainan, pemberian tugas, diskusi, dan presentasi dapat meningkatkan pemahaman dan kemampuan peserta tentang konsep dan pengembangan metode pembelajaran untuk meningkakan keterampilan sosial anak TK. Metode pelatihan intervensi yang diterapkan oleh (Bustan \& Fitria, 2017) juga terbukti dapat meningkatkan pengetahuan peserta tentang rancangan dan pelaksanaan kurikulum berbasis karakter pada anak. Selanjutnya hasil penelitian (Rohendi, Sutarno, \& Ginanjar, 2010) menyatakan bahwa metode pembelajaran demonstrasi efektif terhadap peningkatan hasil belajar siswa kelas $X$ pada mata pelajaran Keterampilan Komputer dan Pengelolaan Informasi di sekolah menengah kejuruan. Hasil kegiatan pengabdian ini memberikan penguatan bahwa metode training, sharing knowledge dan praktik langsung (demonstrasi) tidak hanya efektif diterapkan dalam pembelajaran di Sekolah tetapi juga efektif digunakan dalam kegiatan-kegiatan pelatihan seperti yang telah dilaksanakan oleh pengabdi.

Adanya kerjasama yang baik dari anggota pengabdi, dukungan pimpinan pengabdi dan ketua Gugus Muara Tami, Kotamadya Jayapura, serta antusiasme peserta dalam mengikuti kegiatan menjadi hal penting yang mendukung keberhasilan kegiatan ini. Kesulitan komunikasi akibat akses terhadap jaringan seluler yang terbatas, serta situasi keamanan di Papua (demonstrasi rasisme) sebelum kegiatan dilaksanakan menjadi faktor penghambat yang ditemui dalam pelaksanaan kegiatan pengabdian ini.

\section{SIMPULAN DAN SARAN \\ Simpulan}

Kegiatan pelatihan penerapan multimetode dalam pengembangan perilaku anak usia dini bagi guru-guru PAUD/TK gugus Muara Tami, Kotamadya Jayapura dinyatakan berhasil dengan baik, yang ditunjukkan dari 26 peserta, terdapat 20 
peserta $(76,92 \%)$ yang termasuk kategori sangat baik dan 6 peserta $(23,08 \%)$ termasuk kategori baik. Peserta pada umumnya memberikan respons yang sangat positif (ditunjukkan dengan minat yang sangat tinggi) terhadap kegiatan ini dan mengharapkan adanya kegiatan-kegiatan serupa pada masa mendatang.

\section{Saran}

Disarankan kepada pembaca untuk dapat mengadakan kegiatan pelatihan atau workshop secara berkelanjutan untuk membina dan mengembangkan profesionalisme guru PAUD/TK dalam melaksanakan tugasnya. Jika memungkinkan kegiatan serupa dapat dilaksanakan di daerah-daerah pedalaman yang mengalami keterbatasan akses terhadap sumber belajar yang mutakhir (terbaru).

\section{DAFTAR PUSTAKA}

Adisusilo, S. (2012). Pembelajaran Nilai Karakter. Jakarta: PT Raja Grafindo Persada.

Bustan, R., \& Fitria, N. (2017). Pelatihan Kiat Membangun Karakter Anak. Jurnal $A L$ AZHAR INDONESIA SERI HUMANIORA, 4(1), 25-33.

Gunarti, W., Suryani, L., Muis, A., \& Pratiwi, N. (2018). Metode Pengembangan Perilaku dan Kemampuan Dasar Anak Usia Dini. Jakarta: Universitas Terbuka.

Helms, D., \& Turner, J. (1994). Exploring Child Behavior. New York: Holt Rinehartand Winston.
Ismaniar. (2010). Metode-Metode Pengembangan Perilaku Hidup sehat Anak Usia Dini. Pedagogi: Jurnal IImiah IImu Pendidikan , 3641.

Jahja, Y. (2011). Psikologi Perkembangan. Jakarta: Kencana.

Muthmainnah, Maryatun, I. B., \& Cholimah, N. (2015). Pelatihan Pengembangan Metode Pembelajaran Untuk Meningkatkan Keterampilan Sosial Anak. Jurnal Pendidikan Anak, IV(2), 616-622.

Notoatmodjo, S. (2003). Pendidikan dan Perilaku Kesehatan. Jakarta: Rineka Cipta.

Rohendi, D., Sutarno, H., \& Ginanjar, M. A. (2010). Efektivitas Metode Pembelajaran Demonstrasi Terhadap Peningkatan Hasil Belajar Siswa Kelas X Pada Mata Pelajaran Keterampilan Komputer dan Pengelolaan Informasi Di Sekolah Menengah Kejuruan. Jurnal Pendidikan Teknologi Informasi Dan Komunikasi (PTIK), 3(1), 16-18.

Sirjon, Mulyanie, E. S., \& Tumaruk, H. (2021). Hubungan Pemberian Reward Dengan Sikap Disiplin Anak. Jurnal Smart PAUD, 4(1),

30-37. http://doi.org/10.36709/jspaud.v4i1.15307 